\title{
Race is on to find successor to Varmus at NIH
}

\section{Washington}

The US government last week launched an expedited search for a new director of the National Institutes of Health (NIH), banking against long odds that it will be able to get a nominee confirmed before the presidential election next November.

Donna Shalala, the Secretary of Health and Human Services, charged the president of the National Academy of Sciences (NAS) with producing an unranked list of six to twelve names by mid-November. "We feel strongly that there should be a seamlessness in leadership at NIH," Shalala said in a statement.

The $\$ 16$ billion-a-year biomedical agency will be without a permanent director from the end of the year, when Harold Varmus leaves to become president of the Memorial SloanKettering Cancer Center in New York City (see Nature 401, 627; 1999). Deputy director Ruth Kirschstein will become acting director.

Bruce Alberts, the NAS president, says the Clinton administration hopes to see the Senate act on a nominee next spring. The Senate must confirm NIH directors but, before the administration sends a nomination to the Senate, it conducts a lengthy background check and political vetting. If a nomination does not arrive in the Senate by late winter or early spring, observers say, the odds of a confirmation become vanishingly small, because of the length of the confirmation process and the vagaries of election year politics.

The Senate tends to slow nominations as elections approach, to give the incoming administration a chance to make important

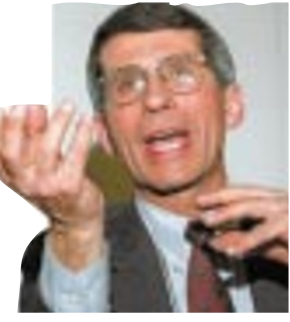

Fauci: known for his work on AIDS crisis.

appointments. The NIH directorship is also a key target for conservative Republicans especially those facing re-election in antiabortion states. Some are said to be planning to make the nominee's position on stem-cell research a litmus test.

Getting the nomination through "will be a challenge", said one Republican aide to the Senate Health and Education Committee. "The position offers so many opportunities for people to take symbolic stands on issues in an election year."

The insecurity of an appointment made by a waning administration may deter potential candidates, who could find themselves out of work after a change of administration. Elizabeth Marincola, executive director of the American Society for Cell Biology, says the conventional wisdom is that "nobody in their right mind would take a job under those circumstances". The solution, she says, is a candidate with "such incredible credentials that he would be almost immune to a turnover in administration. It's completely dependent on

\section{Surprise boost for stem-cell work}

\section{Washington}

Strom Thurmond (Republican, South Carolina), a powerful conservative and the senior member of the US Senate, has testified in favour of allowing stem-cell research at the National Institutes of Health (NIH), increasing the chances that the Congress will allow public funding of research on stem cells derived from human embryos.

Thurmond's testimony showed that some anti-abortion politicians in the United States, who might have opposed such research, will support NIH funding for stem-cell research on the basis of its potential health benefits.

"The NIH must be actively involved in stem-cell research," the 96-year-old senator told a 4 November hearing of the appropriations subcommittee for labour, health and education, chaired by Arlen Specter (Republican, Pennsylvania). "NIH financial support of this research will allow us to move toward clinical applications."
As a measure of Thurmond's influence, Specter estimated at the hearing that Thurmond's previous support for federal funding of fetal-tissue research had doubled the number of Senate votes in its favour, from about 40 to 80 .

Supporters of stem-cell research hope that Thurmond's testimony will encourage other conservatives in the House of Representatives and the Senate to support federal funding. Senator Trent Lott (Republican, Mississippi), the leader of the Senate, has promised that it will consider legislation on the matter in February.

At the same hearing, Congressman Jay Dickey (Republican, Arkansas) reiterated his opposition to stem-cell research and to the NIH's position, which is that it will not pay for extraction of stem cells from embryos, but will pay for research using cells that have been extracted by private organizations. Dickey predicts that the NIH's position will be challenged in the courts. Colin Macilwain the quality of person they recruit."

Alberts has contacted more than 1,000 scientists and scientific organizations. "Shalala would like her nominee to be a widely recognized, distinguished scientist," he wrote in a letter requesting the names of suggested candidates by last Monday ( 8 November).

Alberts told Nature that Shalala did not insist that candidates should be physicians, although most NIH directors have been medical doctors. He said that an overt political affiliation would rule out a candidate.

Among the key names being mentioned as potential nominees in Washington biomedical research circles are Anthony Fauci, director of the National Institute of Allergy and Infectious Diseases, and Richard Klausner, director of the National Cancer Institute.

Fauci, 58, who has been at the NIH since 1968 , developed a national profile as the top official in the agency battling against the AIDS crisis. "He has been on every talk show 15 times. And he has handled a complex political and scientific challenge," says Mike Stephens, a lobbyist for the Federation of American Societies for Experimental Biology.

Fauci was offered - but declined - the NIH directorship by President George Bush. This could work for him in the Republicancontrolled Senate, but might deter the Clinton administration.

Klausner, 48, a Varmus protégé, has been at NIH since 1979. He earned a reputation as an able administrator by heading a review of the NIH's intramural programme which resulted in its modernization, but he is not as well known as Fauci. His success in leading the largest NIH institute since 1995 - and persuading Congress of the importance of cancer research - are clear strengths.

Francis Collins, 49, director of the National Human Genome Research Institute, is being named by some as another strong internal candidate.

Names of outside candidates being floated include Michael Brown, 58, and Joseph Goldstein, 59, of the University of Texas Southwestern Medical Center at Dallas. Together they won the 1985 Nobel Prize for Physiology or Medicine for the discovery of the low-density lipoprotein receptor, and how mutations in it cause familial hypercholesterolaemia.

Also being mentioned are J. Michael Bishop, 63, chancellor of the University of California at San Francisco, who shared the Nobel prize with Varmus in 1989 for the discovery of the cellular origin of retroviral oncogenes; and Eric Lander, 42, who directs the Whitehead Institute/MIT Center for Genome Research in Cambridge, Massachusetts.

Herb Pardes, 65, vice-president for health sciences and dean of the faculty of medicine at Columbia University, New York, is considered a contender by some. Meredith Wadman 